\title{
Knowledge and Attitude of Family Members of Patients of Oral Squamous Cell Carcinoma - A Survey
}

\author{
Suvarna Kizhakkoottuํ, K. R. Don², Herald J. Sherlin³, Gifrina Jayaraj4, Archana Santhanam \\ 1,2, 3, 4, 5 Department of Oral Pathology, Saveetha Dental College and Hospitals, Saveetha Institute of Medical \\ and Technical Sciences (SIMATS), Saveetha University, Chennai, Tamilnadu, India.
}

\section{ABSTRACT}

\section{BACKGROUND}

In India the influence of family members on the treatment decision of oral cancer patients is paramount. Knowledge and attitude about a disease can significantly affect healthcare seeking behaviour and thus ultimately the outcome of a disease especially in chronic diseases like cancer. The aim of this study was to assess the knowledge and attitude towards oral cancer among family members of patients affected with oral squamous cell carcinoma.

\section{METHODS}

In this hospital based cross sectional study $(n=26)$, the relatives of cancer patients were interviewed about their knowledge and perception about various aspects of cancer. Convenience sampling method was performed and the sample size estimation was also done at conveniences. The interview was based on a pre-structured questionnaire containing 22 open ended and closed ended (yes / no) questions given in their native language. Chi square test was used for evaluating the association of survey parameters.

\section{RESULTS}

There is a good sense of basic awareness in the relatives about oral cancer and its causes. Understanding levels of relatives were poor on the treatment plans and its side effects. Belief of oral cancer curability was more in female relatives. This was statistically significant with a $p$ value $=0.033$. A statistically significant relation was obtained between the gender and belief of relatives on the causes of cancer ( $p$ value $=0.013)$.

\section{CONCLUSIONS}

Awareness programs and counselling should be organised for patients to make them aware of the treatment plans and its side effects. More programs also need to be organised at institutional levels and public level to help individuals restrain from habits like smoking and tobacco usage.

\section{KEY WORDS}

Awareness, Family Members, Knowledge, Oral Cancer, Oral Squamous Cell Carcinoma, Relatives
Corresponding Author:

Dr. Don K.R.,

Department of Oral Pathology, Saveetha Dental College and Hospitals, Saveetha Institute of Medical and Technical Sciences (SIMATS), Saveetha University, Chennai, Tamilnadu, India.

E-mail:drkrdon@gmail.com

DOI: $10.14260 /$ jemds $/ 2020 / 870$

How to Cite This Article:

Kizhakkoottu S, Don K.R, Sherlin H.J, et al Knowledge and attitude of family members of patients of oral squamous cell carcinoma - a survey. J Evolution Med Dent Sci 2020;9(52):3982-3987, $10.14260 /$ jemds $/ 2020 / 870$ DOI:

Submission 21-09-2020,

Peer Review 03-11-2020

Acceptance 11-11-2020,

Published 28-12-2020.

Copyright (C) 2020 Suvarna Kizhakkoottu et al. This is an open access article distributed under Creative Commons Attribution License [Attribution 4.0 International (CC BY 4.0)] 


\section{BACKGROUND}

Oral cancer is one of the most common cancers and accounts for $2-4 \%$ of all cancer cases in the world. ${ }^{1}$ India has the highest number of oral cancer cases (approximately $20 \%$ ) in the world. ${ }^{1} 90 \%$ of all the oral cancer cases fall under oral squamous cell carcinoma and which is the most common malignancy of oral cavity in India. 1,2 The clinical outcome of the oral carcinoma cases has remained poor despite all the diagnostic and therapeutic advancements.

In India, family members play a significant role in providing care to the patient and in the decision making phase of treatment. Studies earlier reported in literature on the involvement of family in decision making resulting in increased patient satisfaction and regular treatment follow ups.,3 Not many studies are present on the involvement of family members in decision making related to oral cancer. Even though the collective decision making process and the number of individuals involved in decision making may vary from country to country, the collective decision making process is not unique to any particular country by any means. ${ }^{5}$

One of the previous studies from a cancer center in the USA found that wide disagreement in concerned families about treatment of a patient affected various steps of treatment like choice of doctor, hospital, treatment protocol and pathway of care. ${ }^{5}$ In a few cases, families of patients choose not to inform the result of diagnosis with patients as it may affect their loved one's mental well-being. ${ }^{6}$ For such patients, the role of families in decision-making becomes central to their care. There is no proper study to assess the factors affecting the decision making of family members in the South Indian population. This study is aimed at assessing the knowledge and attitude about oral cancer in family members of patients affected with Oral Squamous Cell Carcinoma.

\section{METHODS}

The present study was conducted with approval from the institutional human ethical committee. This hospital based cross sectional study was conducted between October and December 2019. This questionnaire study included a sample size of $n=26$. Convenience sampling method was performed and the sample size estimation was also done at conveniences. Responses were collected from the relatives of patients visiting the oral oncology outpatient department, for review and radiotherapy. The purpose and nature of the study were explained to the participants in their native language. Upon agreement the concerned relatives were directed to a separate counselling room away from the concerned patient and asked to sign a consent form in their native language before proceeding with the interview. After obtaining written consent the relatives were interviewed about their knowledge, perception and attitude about various aspects of cancer. The interview was based on a pre-structured questionnaire containing 22 questions, which consists of both open ended and closed ended (yes / no) questions given in their native language.

\section{Inclusion Criteria}

Only close relatives of diagnostically confirmed cases of oral squamous cell carcinoma were included. Age equal to or greater than 18 were included in the study.

\section{Statistical Analysis}

IBM SPSS Statistics 23 software was used for statistical analysis. Descriptive statistics was used to analyse the data and chi square test was used for evaluating the association of survey parameters. $\mathrm{P}$ value less than 0.05 was considered statistically significant.

\section{RESULTS}

In demographic data analysis $57.7 \%$ of the relatives interviewed in the present study, were found to be males and $42.3 \%$ were females.

\begin{tabular}{|c|c|c|c|}
\hline $\begin{array}{l}\text { SL. } \\
\text { No. }\end{array}$ & Questions & Choices & $\begin{array}{c}\text { No of Responses } \\
\text { (Percentage \%) }\end{array}$ \\
\hline 1 & Have you heard of oral cancer? & $\begin{array}{l}\text { Yes } \\
\text { No }\end{array}$ & $\begin{array}{l}92 \% \\
8 \%\end{array}$ \\
\hline 2 & $\begin{array}{l}\text { How did you get information } \\
\text { about oral cancer? }\end{array}$ & $\begin{array}{c}\text { Media } \\
\text { Books } \\
\text { Awareness programs }\end{array}$ & $\begin{array}{l}83 \% \\
9 \% \\
8 \%\end{array}$ \\
\hline 3 & $\begin{array}{l}\text { What do you think is the main } \\
\text { cause of oral cancer? }\end{array}$ & $\begin{array}{c}\text { Tobacco } \\
\text { Smoking } \\
\text { Tobacco \& smoking } \\
\text { Drinking }\end{array}$ & $\begin{array}{c}57.7 \% \\
4 \% \\
30.8 \% \\
8 \%\end{array}$ \\
\hline 4 & $\begin{array}{l}\text { Do you know about the habits or } \\
\text { predisposing factors which lead to } \\
\text { this disease? }\end{array}$ & $\begin{array}{l}\text { Yes } \\
\text { No }\end{array}$ & $\begin{array}{l}88 \% \\
12 \%\end{array}$ \\
\hline 5 & $\begin{array}{c}\text { Do you think cancer is } \\
\text { preventable? }\end{array}$ & $\begin{array}{c}\text { Yes } \\
\text { No } \\
\text { Don't know }\end{array}$ & $\begin{array}{c}69 \% \\
8 \% \\
23 \%\end{array}$ \\
\hline 6 & $\begin{array}{c}\text { Do you know about the patient's } \\
\text { disease? }\end{array}$ & $\begin{array}{l}\text { Yes } \\
\text { No }\end{array}$ & $\begin{array}{l}88 \% \\
12 \%\end{array}$ \\
\hline 7 & $\begin{array}{l}\text { What was the actual reason for } \\
\text { consultation? }\end{array}$ & $\begin{array}{l}\text { Ulcer } \\
\text { Pain } \\
\text { Swelling } \\
\text { Growth }\end{array}$ & $\begin{array}{c}46.1 \% \\
42.3 \% \\
4 \% \\
8 \%\end{array}$ \\
\hline 8 & $\begin{array}{l}\text { Is there any family history of } \\
\text { cancer }\end{array}$ & $\begin{array}{l}\text { Yes } \\
\text { No }\end{array}$ & $\begin{array}{l}19.2 \% \\
80.8 \%\end{array}$ \\
\hline 9 & $\begin{array}{l}\text { Do you think there was a delay in } \\
\text { consulting the doctor }\end{array}$ & $\begin{array}{l}\text { Yes } \\
\text { No }\end{array}$ & $\begin{array}{l}46.2 \% \\
53.8 \%\end{array}$ \\
\hline 10 & $\begin{array}{l}\text { If yes, do you think the delay will } \\
\text { aggravate the current disease? }\end{array}$ & $\begin{array}{l}\text { Yes } \\
\text { No }\end{array}$ & $\begin{array}{c}100 \% \\
0 \%\end{array}$ \\
\hline 11 & $\begin{array}{l}\text { Do you know the type of oral } \\
\text { cancer of your relative? }\end{array}$ & $\begin{array}{l}\text { Yes } \\
\text { No }\end{array}$ & $\begin{array}{c}4 \% \\
96 \%\end{array}$ \\
\hline 12 & $\begin{array}{l}\text { Do you have any difficulty in } \\
\text { understanding what doctors or } \\
\text { staff members communicate? }\end{array}$ & $\begin{array}{l}\text { Yes } \\
\text { No }\end{array}$ & $\begin{array}{l}42.3 \% \\
57.7 \%\end{array}$ \\
\hline 13 & $\begin{array}{l}\text { Do you think this disease can } \\
\text { spread from one site to another } \\
\text { site? }\end{array}$ & $\begin{array}{c}\text { Yes } \\
\text { No } \\
\text { Don't know }\end{array}$ & $\begin{array}{c}84.7 \% \\
0 \% \\
15.3 \%\end{array}$ \\
\hline 14 & $\begin{array}{c}\text { Are you aware of the steps in the } \\
\text { treatment? }\end{array}$ & $\begin{array}{l}\text { Yes } \\
\text { No }\end{array}$ & $\begin{array}{c}4 \% \\
96 \%\end{array}$ \\
\hline 15 & Do you think cancer is curable? & $\begin{array}{c}\text { Yes } \\
\text { No } \\
\text { Don't know }\end{array}$ & $\begin{array}{c}57.7 \% \\
0 \% \\
42.3 \%\end{array}$ \\
\hline 16 & Do you think cancer can reoccur? & $\begin{array}{c}\text { Yes } \\
\text { No } \\
\text { Don't know }\end{array}$ & $\begin{array}{l}53.8 \% \\
19.2 \% \\
26.9 \%\end{array}$ \\
\hline 17 & $\begin{array}{c}\text { Do you know the side effects of } \\
\text { treatment? }\end{array}$ & $\begin{array}{l}\text { Yes } \\
\text { No }\end{array}$ & $\begin{array}{l}7.7 \% \\
92.3 \%\end{array}$ \\
\hline 18 & $\begin{array}{l}\text { What do you think of living with a } \\
\text { Cancer patient? }\end{array}$ & $\begin{array}{l}\text { Difficult } \\
\text { Okay } \\
\text { Sympathetic }\end{array}$ & $\begin{array}{l}61.5 \% \\
15.4 \% \\
23.1 \%\end{array}$ \\
\hline
\end{tabular}


Out of all cases surveyed in this study, $92 \%$ of the family members have heard of oral cancer. $83 \%$ of the family members were aware about oral cancer through the media. Most of the family members were aware of the major causes of cancer. $57.7 \%$ felt that the major cause of oral cancer is tobacco whereas $30.8 \%$ felt that the causative factor for oral cancer is both tobacco and smoking. Majority of the relatives particularly females felt that tobacco is the main cause of cancer; chi-square test $p$ value $=0.013$. (Figure 1 ). $88 \%$ of the family members believed that lifestyle habits can lead to this disease. $69 \%$ of the study population said that oral cancer could be prevented. When considering the gender, $73.33 \%$ of male and $63.64 \%$ of female relatives felt that cancer is preventable (Figure 2). $46.1 \%$ of the cases reported in this study had ulcers as the major reason for consultation followed by pain accounting for $42.3 \%$ of the reported cases. $19.2 \%$ of the patients had a previous history of cancer in their families (Table 1).

The query on the delay in consultation gave a mixed response with $53.8 \%$ feeling that there was no delay in consultation. However, $100 \%$ of the relatives believed that the disease will aggravate further if consultation is not done. $96 \%$ of the relatives were not aware of the type of cancer of their loved ones, even though $57.7 \%$ stated they don't have any difficulty in understanding what the doctors communicate. There was a feeling among the $84.7 \%$ of population in this study that the disease can spread from one site to the other. It was observed that a consensus was present among male and female relatives on the metastatic potential of oral cancer. There is also a lack of awareness on the relative's part on the steps of treatment and $96 \%$ of the relatives in this study were not aware of the treatment procedure.

It is observed from the study that there is a sense of optimism with the patient's relatives as $57.7 \%$ of the people believe that oral squamous cell carcinoma is curable and females had a stronger feeling that cancer is curable than men. This was statistically significant with $\mathrm{p}=0.033$ (Figure 3). 53.8 $\%$ of relatives felt that this disease can reoccur. Male relatives strongly felt that there is a chance of recurrence of oral cancer but female relatives had a mixed response about the recurrence of oral cancer. Only $7.7 \%$ of the relatives were aware of the side effects of treatment despite most of the patients having undergone radiotherapy. $61.5 \%$ of the relatives felt living with a cancer patient was difficult. $60 \%$ of male and $63.64 \%$ of female relatives felt that it is difficult living with a cancer patient (Figure 4).

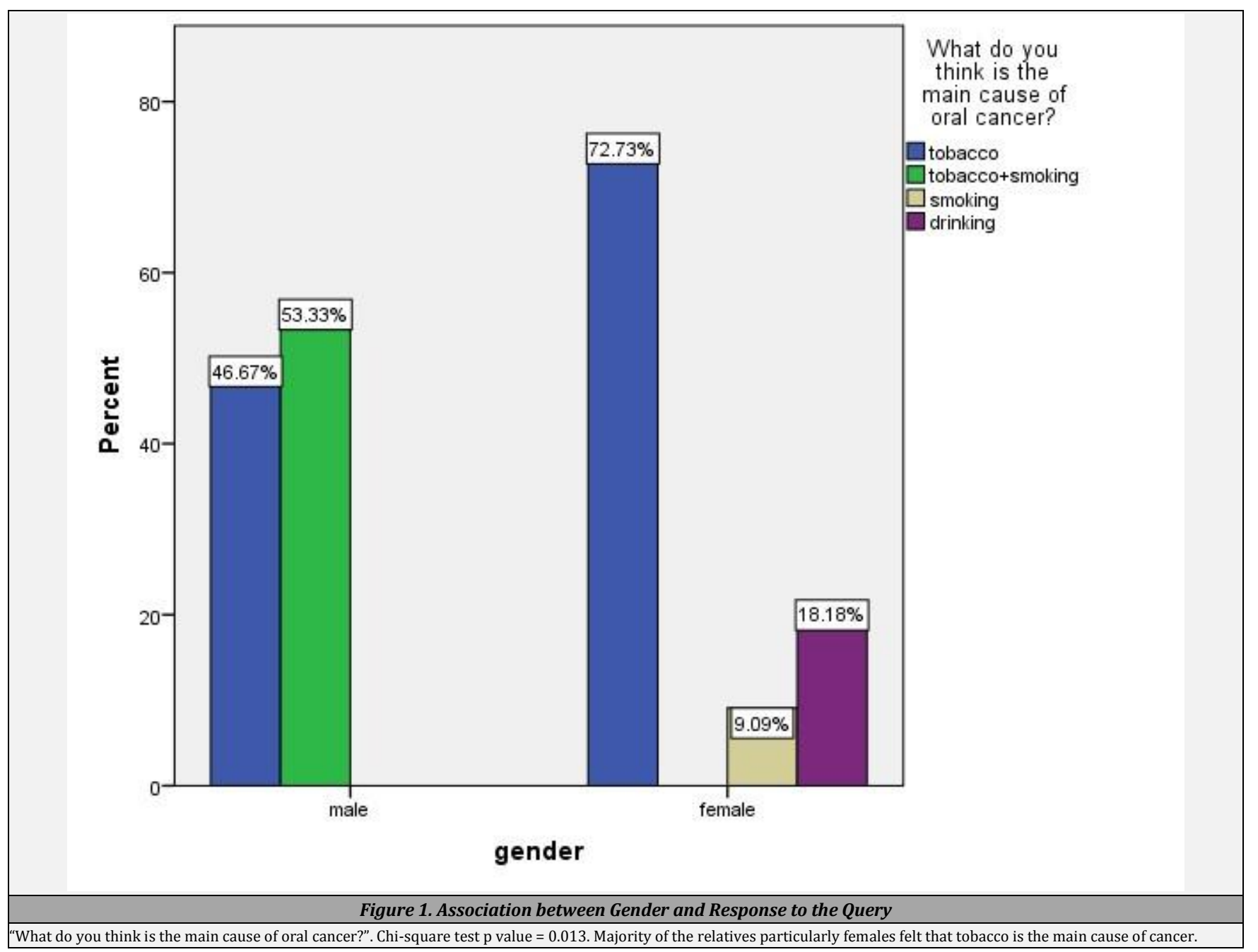




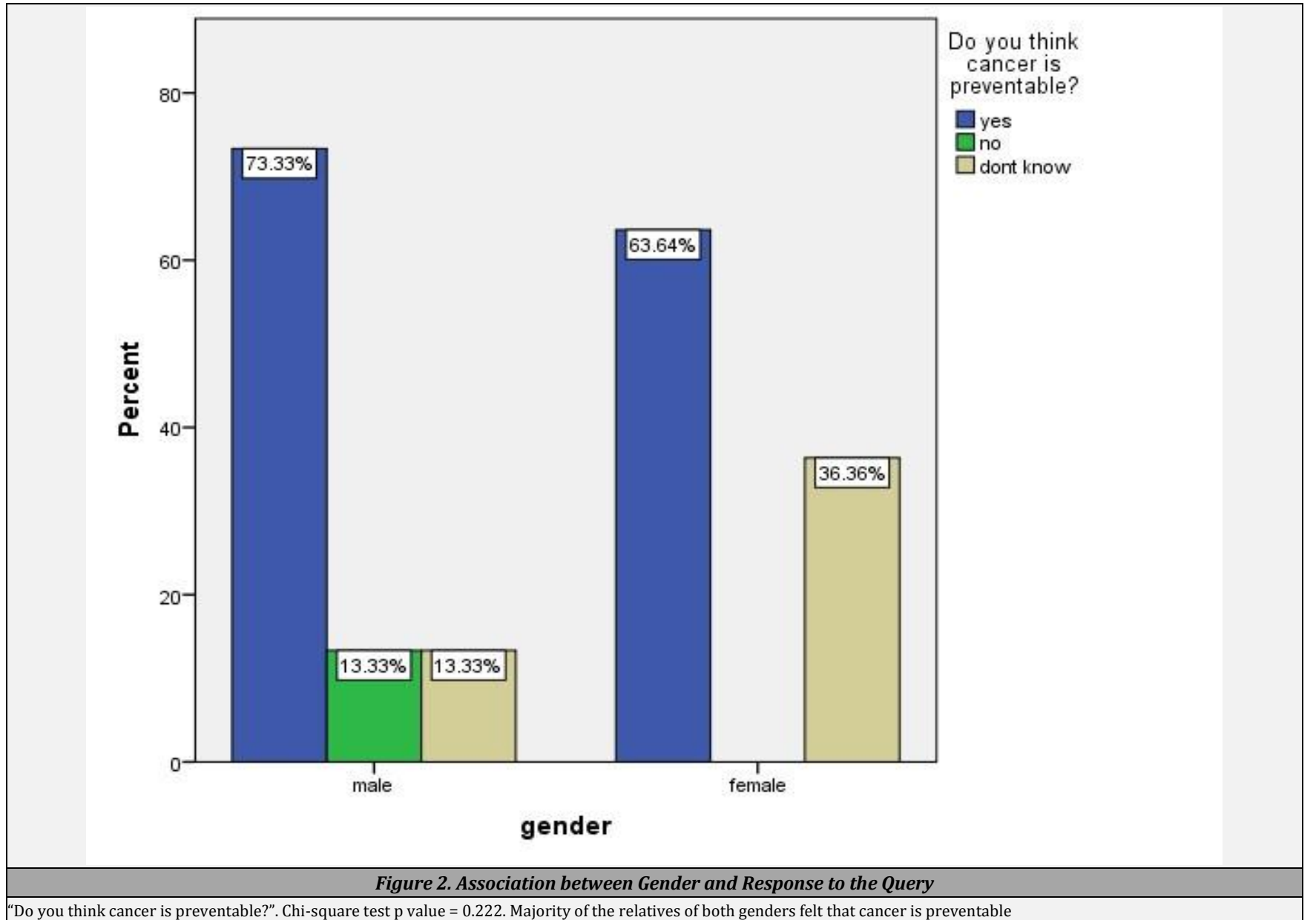

“Do you think cancer is preventable?". Chi-square test p value $=0.222$. Majority of the relatives of both genders felt that cancer is preventable

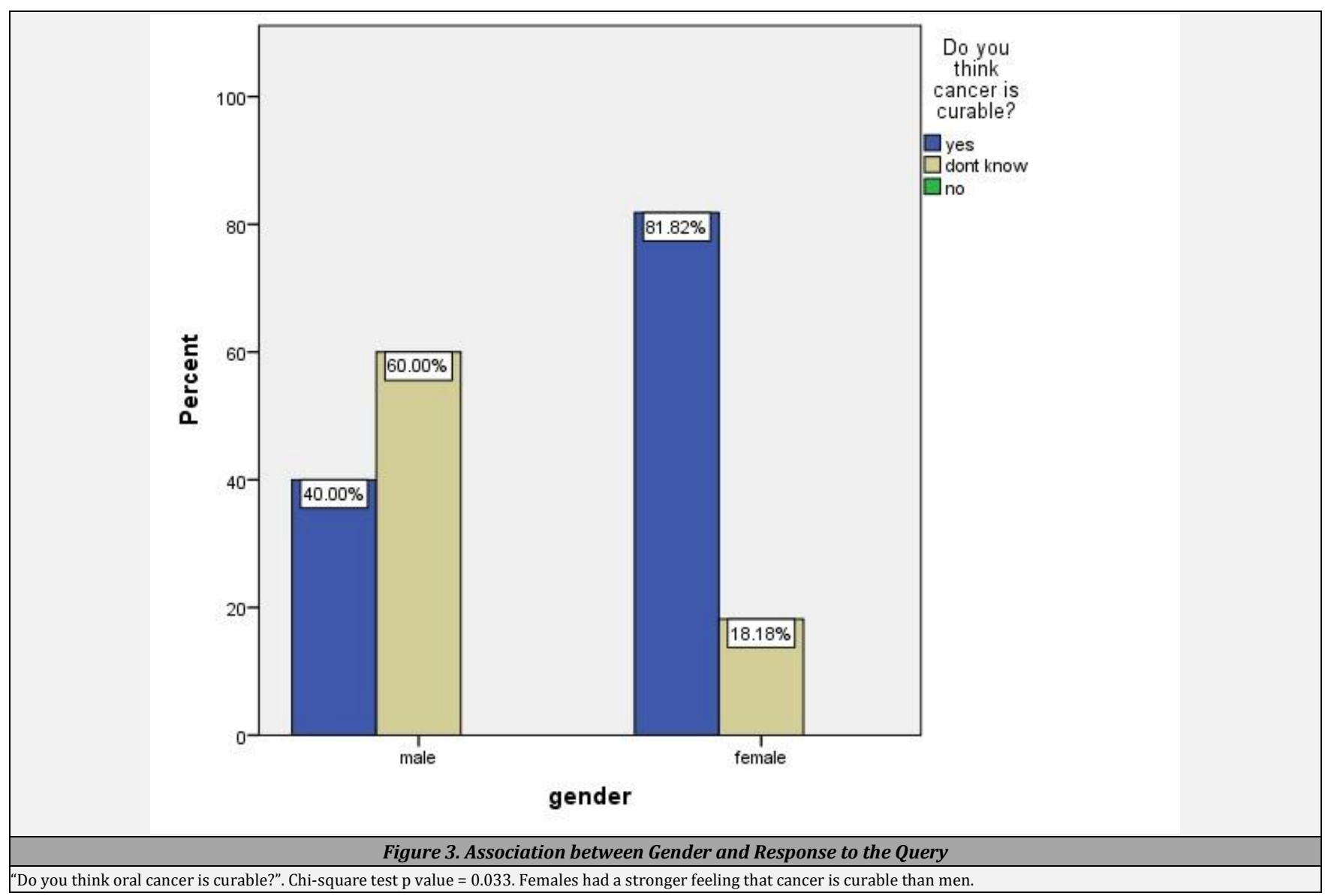




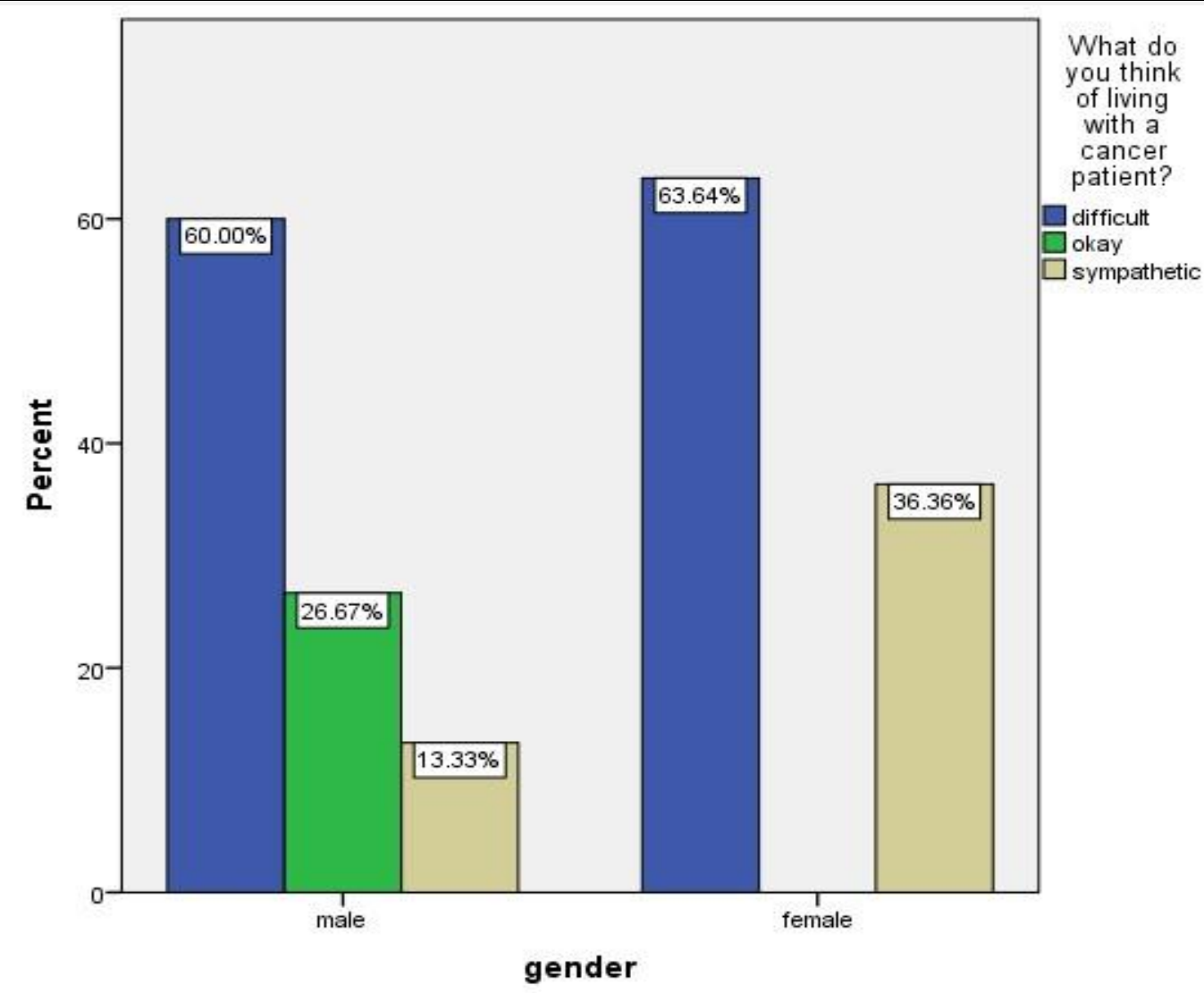

Figure 4. Bar Graph Showing the Association between Gender and Their Response to the Query

"What do you think of living with a cancer patient?". Chi-square test p value $=0.110$. Both male and female relatives felt that it is difficult living with a cancer patient.

\section{DISCUSSION}

The knowledge and perceptions of family members of patients about oral cancer and its prognosis and treatment is very important in a country like India because oral cancer is the most common cancer in India amongst men $(16.1 \%$ of all cancers) according to the Globocan 2018 data. $^{7}$

In a developing country like India, a high percentage of oral cancer patients are from lower socioeconomic classes. The association between the predominance of oral cancer and low socioeconomic status was stated by Conway et al. and Edwards and Jones.8,9 Low socioeconomic status coupled with lack of awareness of the disease can lead to delayed treatments which can have devastating effects on the family and the patient. This survey was aimed at assessing the knowledge level and attitude, on oral cancer, of family members of patients affected with Oral Squamous Cell Carcinoma.

In this survey, it was observed that the majority of the relatives are aware of oral cancer and most of them have heard of oral cancer through the media. This could be due to various initiatives and campaigns by the government that have really helped in increasing awareness on oral cancer in the general public. Media plays a major role in this regard. All movies telecasted in big screen and small screen convey a message before starting the show on oral cancer and the effect of habits on cancers. The effect of this was clearly seen in the survey results. Most of the population believe that habits like usage of tobacco and its products is the major cause of oral cancer. A statistically significant relation was obtained between the gender and belief of relatives on the causes of oral cancer ( $p$ value $=0.013$ ) (Figure 1 ) .

Majority of the population believe that cancer is preventable. This may be due to the strong belief among patients that habits are the major cause of oral cancer. Oral ulceration (46.1\%) and pain (42.3\%) accounted for the major cause of consultation in the present study. The predominance of oral ulceration as the most common clinical presentation of oral cancer was also stated by Wong and Wiesenfeld in 2018.10 Cuffari et al. in 2006 also stated the significance of pain as the first symptom of oral cancer in their hospital based descriptive study. ${ }^{11}$

$19.2 \%$ of the reported patients had family history of cancers. This may be due to the possibility of genetic inheritance from ancestors as reported in some of the previous studies. ${ }^{12} 46.2 \%$ of the relatives felt that there was a delay in consultation and all of them believed that the delay will aggravate the disease. This delay could be due to some of the earlier discussed factors like poor socioeconomic status and lack of awareness. Most of the relatives were not aware of the type of cancer of the patient, its treatment plans and side effects which may be due to their poor awareness. It was quite evident from this study that even the relatives of patients who were undergoing radiation therapy were not aware about the side effects of radiation like decreased salivation, radiation induced mucositis and osteoradionecrosis, ${ }^{13}$ this could be due to the communication gap between hospital staff and also could be due to the poor awareness of patients and relatives. In the present study itself, $42.3 \%$ of the relatives felt that they have difficulty in understanding what doctors or hospital staff communicate. Hence more emphasis should be given at the 
institutional level to educate the patients and family about the overall treatment plan and side effects of oral cancer treatment.

$84.7 \%$ of the study population were aware that the aggressive type of oral cancer leads to metastases to other sites like lymph nodes. ${ }^{14,15} 57.7 \%$ of relatives had a general feeling that cancer is curable. $19.2 \%$ of the relatives stated that cancer will not reoccur and $29.6 \%$ stated that they were not sure about the recurrence of cancer. The above responses from the relatives may be subjective as these responses were predominantly based on their previous family experiences of cancer and also based on the social experiences. Females had a stronger feeling that cancer is curable than men. A statistically significant relation was obtained between the gender of relatives and their response to the query "Is cancer curable" with a $\mathrm{p}$ value $=0.033$.

$61.5 \%$ of the relatives feel that it is difficult living with a cancer patient. This may be primarily because of economic factors like the cost of cancer treatment and also the difficulty of the relatives in witnessing the hardships which their loved ones have to undergo during the course of treatment.

Limitations of this survey include low sample size, hospital based study design and limited geographic area of coverage.

\section{CONCLUSIONS}

Even though there is a good sense of basic awareness in the relatives about oral cancer and its causes, there is a need for creating better awareness on the available treatment options. Awareness programs and counselling options should be organised for patients to make them more aware of the treatment plans and its side effects. Though the relatives were aware of the effect of habits on oral cancer susceptibility, habits cessation of individuals remains a big challenge. More programs need to be organised at institutional levels and public level to help individuals restrain from habits like smoking and tobacco usage. Public should be made aware of the government schemes providing monetary support to cancer patients so that delay in availing treatment due to economic factors will not result in loss of even a single life. Knowledge and awareness of family members on oral cancer can influence the prognosis and treatment plan of oral cancer patients. Good awareness among family members will result in early diagnosis and improved recovery rates in patients.

Data sharing statement provided by the authors is available with the full text of this article at jemds.com.

Financial or other competing interests: None.

Disclosure forms provided by the authors are available with the full text of this article at jemds.com.

\section{REFERENCES}

[1] Singh MP, Kumar V, Agarwal A, et al. Clinicoepidemiological study of oral squamous cell carcinoma: a tertiary care centre study in North India. J Oral Biol Craniofac Res 2016;6(1):31-4.

[2] Don KR, Ramani P, Ramshankar V, et al. Promoter hypermethylation patterns of P16, DAPK and MGMT in oral squamous cell carcinoma: a systematic review and meta-analysis. Indian J Dent Res 2014;25(6):797-805.

[3] Soriano G, Landrum MB, Weeks JC, et al. The role of families in decisions about cancer treatments. J Clin Orthod 2013;31(15 Suppl):6528-8.

[4] Zhang AY, Siminoff LA. The role of the family in treatment decision making by patients with cancer. Oncol Nurs Forum 2003;30(6):1022-8.

[5] Paul R, Sinha S, Md. Asifullah, et al. Knowledge, attitude and practices of patients' relatives about cancer: a study from Eastern India. Int J Community Med Public Health 2017;4(4):1342-7.

[6] McCabe MS, Wood WA, Goldberg RM. When the family requests withholding the diagnosis: who owns the truth? J Oncol Pract 2010;6(2):94-6.

[7] GLOBOCAN 2018. Cancer IAFR, Others. Global Cancer Observatory 2018.

[8] Conway DI, Brewster DH, McKinney PA, et al. Widening socio-economic inequalities in oral cancer incidence in Scotland, 1976-2002. Br J Cancer 2007;96(5):818-20.

[9] Edwards DM, Jones J. Incidence of and survival from upper aerodigestive tract cancers in the U.K.: the influence of deprivation. Eur J Cancer 1999;35(6):968-72.

[10] Wong T, Wiesenfeld D. Oral cancer. Aust Dent J 2018;63 Suppl 1:S91-9.

[11] Cuffari L, de Siqueira JTT, Nemr K, et al. Pain complaint as the first symptom of oral cancer: a descriptive study. Oral Surg Oral Med Oral Pathol Oral Radiol Endod 2006;102(1):56-61.

[12] Ankathil R, Mathew A, Joseph F, et al. Is oral cancer susceptibility inherited? Report of five oral cancer families. Eur J Cancer B Oral Oncol 1996;32B(1):63-7.

[13] Aravinth H, Don KR, Saravana Dinesh SP. Osteoradionecrosis of mandible - a review. Drug Invention Today 2019;11(1):108-17.

[14] Bedre AS, Don KR. Different grading systems of oral squamous cell carcinoma and their relation to lymph node metastasis - a comparative study. International Journal of Current Research 2017;9(5):50458-64.

[15] Nadar S, Don KR. Metastatic tumours to the jaw and oral cavity - a brief review. International Journal of Current Research 2017;9(5):50362-6. 